\title{
Invited Synthesis Paper: Coyote depredation control: An interface between biology and management
}

\author{
FREDERICK F. KNOWLTON, ERIC M. GESE, AND MICHAEL M. JAEGER
}

Authors are research wildlife biologists, USDA, National Wildlife Research Center, Utah State University, Logan, Ut. 84322-5295; and research wildlife biologist,USDA, National Wildlife Research Center, University of California, Berkeley, Calif. 94720.

\begin{abstract}
Predation by coyotes (Canis latrans) on livestock continues to plague producers in the United States. Agricultural interests are concerned about coyote predation because sheep inventories in the U.S.have declined $>85 \%$ in the past 60 years, with a $25 \%$ decline between 1991 and 1996. This decline in sheep numbers has been attributed to low economic returns among producers, with coyote predation cited as a major causative factor. Generalizations about the magnitude and nature of depredations can be misleading because of the varied nature of sheep operations, including size of operations, differences in management, and environmental circumstances surrounding individual operations. Coyote depredation rates appear to be influenced by sheep management practices, coyote biology and behavior, environmental factors, and depredation management programs. Most nonlethal depredation control techniques fall within the operational purview of the producers. The major controversy regarding depredation management focuses on programs that remove coyotes to prevent or curtail predation on domestic stock, especially on public lands. Differences in the magnitude, nature, and history of problems caused by coyotes, as well as the circumstances in which they occur, dictates a need for a variety of techniques and programs to resolve problems. The resolution of coyote depredation upon livestock remains controversial for producers, resource managers, and the general public. Because various segments of society attach different values to coyotes, resolution of depredations should use management programs that integrate the social, legal, economic, and biological aspects of the animals and the problem. Preferred solutions should involve procedures that solve problems as effectively, efficiently, and economically as possible in the least intrusive and most benign ways. Predation management requires a partnership among producers and wildlife managers to tailor programs to specific damage situations so the most appropriate techniques can be selected. This paper attempts to clarify the issues surrounding depredation management, synthesize past and current research, and provide information to resource managers associated with coyote depredation management. This synthesis integrates current understandings of coyote biology and behavior, the nature of depredations upon sheep producing enterprises, and the merits of various depredation control strategies and techniques.
\end{abstract}

\footnotetext{
Manuscript accepted 23 Apr. 1999.
}

Key Words: coyote, Canis latrans, domestic livestock, predation, management

Control of mammalian predators to protect livestock or enhance game populations has been practiced worldwide for centuries. Manipulation of canid populations, especially reduction of red foxes (Vulpes vulpes), coyotes (Canis latrans), wolves (C. lupus), jackals (C. mesomelas, $C$. aureus), and dingos (C. familiaris dingo), has occurred both historically and currently with mixed results (Harris and Saunders 1993, Reynolds and Tapper 1996). Some canid removal is used as a conservation tool to assist recovery of threatened or endangered species in areas where predators are non-native or overabundant (Garrott et al. 1993). With the popularization of carnivores and establishment of canid populations in the United States, with particular reference to the continued expansion of coyotes (Hilton 1978, Hill et al. 1987, Moore and Parker 1992) and successful reintroduction of wolves (Phillips et al. 1995, Bangs and Fritts 1996), managing conflicts between predators, livestock, and game populations is re-emerging as an issue for resource managers, biologists, and the general public (Mech 1996).

The coyote is one of the most successful, opportunistic, and widely distributed predators in North America (Bekoff and Wells 1986). Predation upon domestic livestock by coyotes is a widespread problem for producers throughout North America (Gier 1968, U.S. Fish and Wildlife Service 1978, Wade 1978, Andelt 1987). Techniques are available to reduce coyote depredations on livestock (Sterner and Shumake 1978, Wade 1978, Fall 1990), but the use of some control techniques and programs continues to be contentious and controversial (Buys 1975, Stuby et al. 1979, Kellert 1985, Andelt 1987, 1996). Many ideas, myths, and misperceptions about coyote depredation management exist; primarily questions regarding: what management techniques are available and effective; the effect of removal on coyote populations; and why is coyote predation on sheep a recurring problem with management programs currently in place? Recent studies of the efficacy of coyote management programs, relative effectiveness of various control measures, and the influence of management programs on coyote demographics suggest a need to synthesize some of these topics (see Andelt 1987, 1996 for reviews on coyote predation). We believe there is a need to address the controversy surrounding coyote depreda- 
tion management, to enlighten resource managers and the general public, and to stimulate discussion and research regarding new avenues of approaching the persistent problem of coyote depredation management. Through this paper, we attempt to synthesize the available information into a comprehensive interpretation and understanding of the relationships between coyote biology and depredation management. We discuss the current understandings of (1) coyote demographics, behavior, and population regulation, (2) the magnitude and factors influencing coyote depredations on livestock, and (3) the merits of various management strategies to alleviate coyote depredations on domestic livestock. We discuss the inter-relationships of the factors influencing coyote predation and management, and the need to understand the depredation issue as it relates to coyote behavior and biology. Our attempt is to provide a science-based perspective on the merits and pitfalls of coyote depredation management.

\section{Coyote Demographics}

Assessing the effect of management programs on coyote populations requires an understanding of the mechanisms and behaviors involved in regulating coyote demographic processes. Coyote demographics and population dynamics have been studied in many areas throughout the U.S. and Canada (e.g., Knowlton 1972, Nellis and Keith 1976, Andelt 1985, Windberg 1995). Coyotes are territorial with territories spaced contiguously across the landscape like pieces of a puzzle (Fig. 1; Bekoff and Wells 1986, Windberg and Knowlton 1988, Gese et al. 1989, 1996a, 1996b) with coyotes often times utilizing physical features, such as rivers and roads, to demarcate territory boundaries (Fig. 2). Each territory is controlled and maintained by a dominant alpha pair (Gese and Ruff 1997, 1998), with associated beta coyotes and pups (Camenzind 1978, Bekoff and Wells 1986, Gese et al. 1996a, 1996b). Pre-whelping pack size ranges from a pair of coyotes to 10 individuals (Gese et al. 1996a). Populations also include transient (Fig. 3) and dispersing individuals (Andelt 1985, Bekoff and Wells 1986, Gese et al. 1989, 1996a). Coyotes are monestrous (Kennelly and

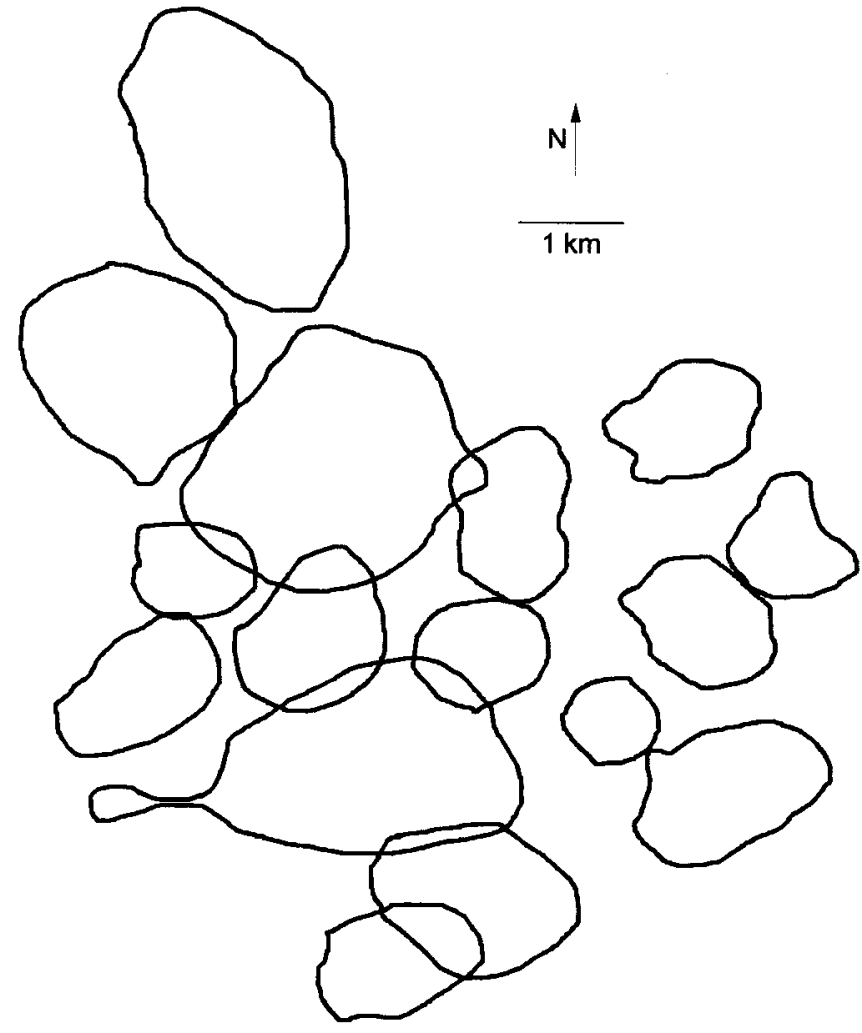

Fig. 1. Territorial boundaries of 16 female coyotes as determined by radiotelemetry locations, Webb County, Texas, 1984-1985 (adapted from Windberg and Knowlton 1988).
Johns 1976), with the dominant breeding pair producing a single litter per territory each spring; beta females may also produce offspring, but this rarely occurs (Gese et al. 1996a). Adults have relatively long reproductive lives $(3-10$ years) and produce average litters of 4 to 8 young. Because stable populations require that on average, breeding adults only recruit enough surviving offspring

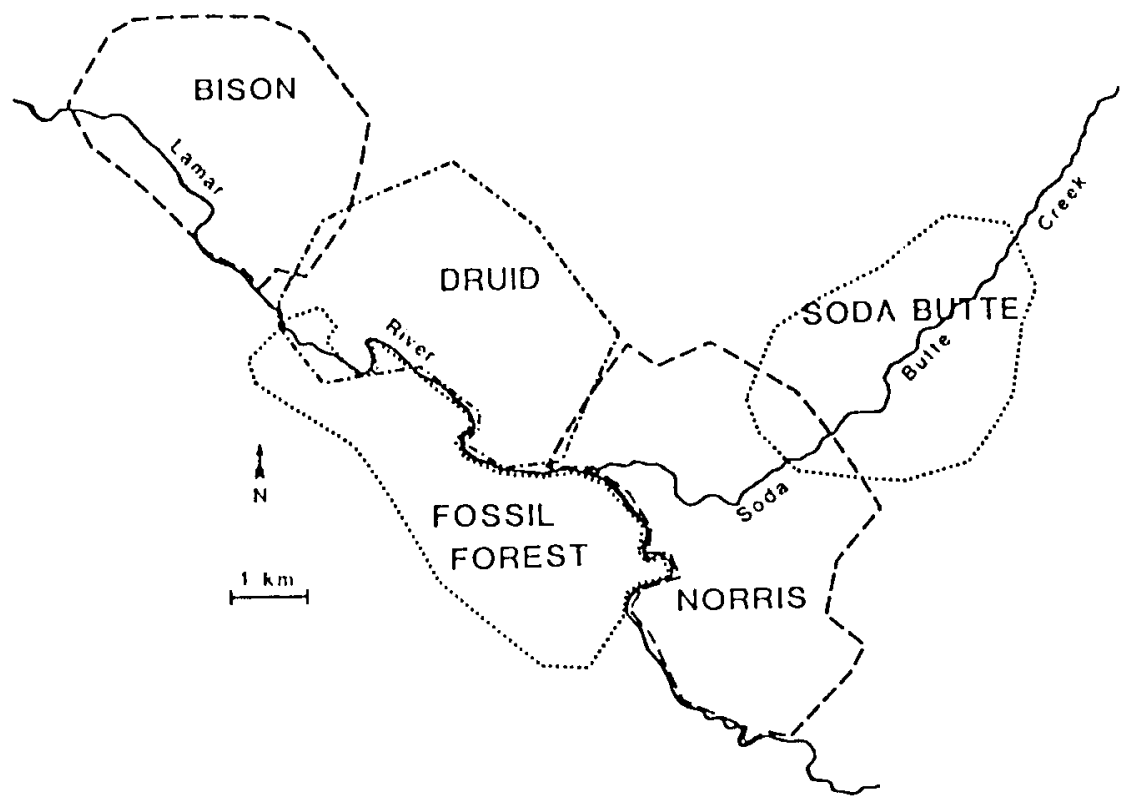

Fig. 2. Territorial boundaries of five resident coyote packs in the Lamar River Valley, Yellowstone National Park, Wyoming, winter of 1990-1991, as determined by visual locations (from Gese et al. 1996a, 1996b). 


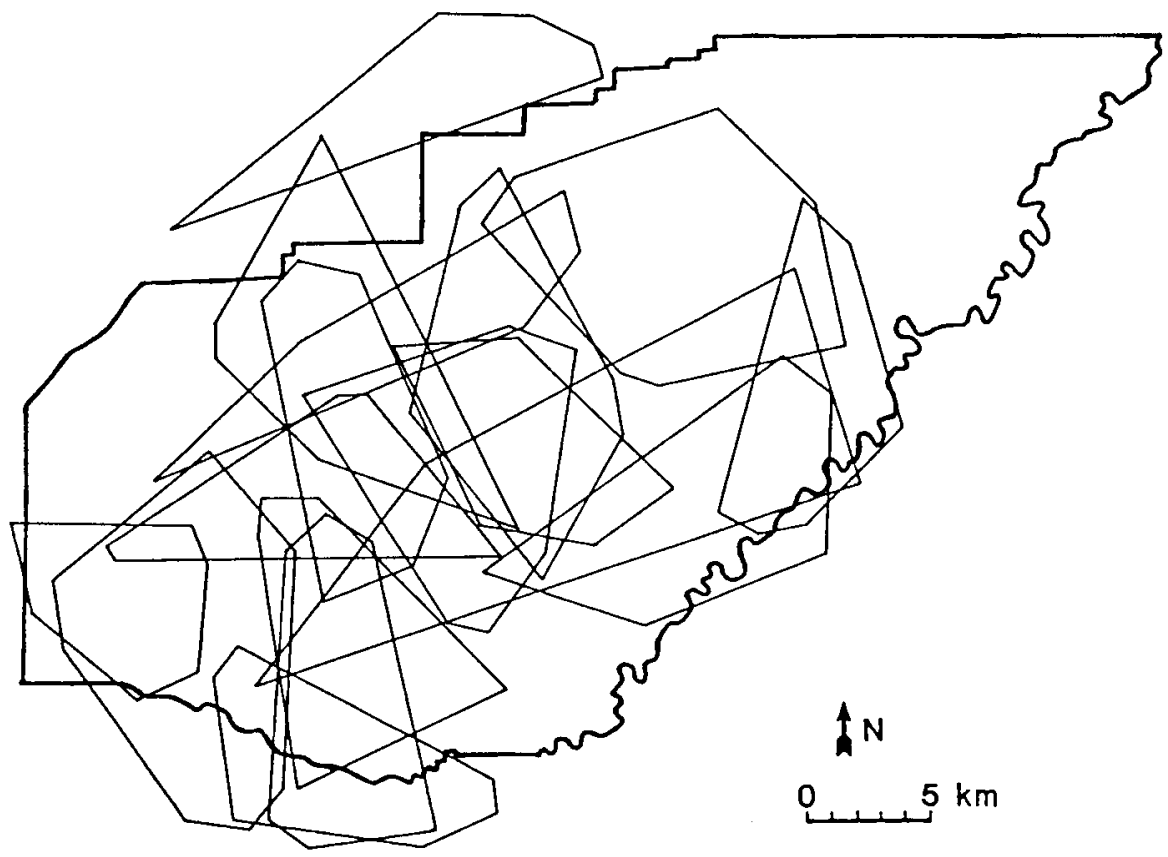

Fig. 3. Home range boundaries of 17 transient coyotes monitored on the Pinon Canyon Maneuver Site, Colorado, 1983-1987 (from Gese et al. 1988).

into the breeding population to replace themselves, less than $10 \%$ of the young from a given pair of coyotes need to survive and reproduce to maintain the population (assuming average reproductive lives of 4 years with litter sizes of 6 young). The other $90 \%$ die, disperse, or fail to reproduce. Hence population regulation is the interplay among the reproductive potential of coyotes and the opposing factors such as reproductive inhibition, mortality, and dispersal.

\section{Factors Regulating Coyote Density}

Estimates of coyote density range from 0.2 to 2.3 coyotes $/ \mathrm{km}^{2}$ with generally increasing densities from northern to southern U.S. Available food, especially in winter (Weaver 1979, Gese et al. 1996a), is the major factor regulating coyote abundance (Gier 1968, Clark 1972), mediated through social dominance and territoriality (Knowlton and Stoddart 1983, Gese et al. 1989, Knowlton and Gese 1995, Windberg 1995). Food abundance regulates coyote numbers by influencing reproduction, survival, dispersal, space-use patterns, and territory density (Gier 1968, Knowlton 1972, Todd et al. 1981, Todd and Keith 1983, Mills and Knowlton 1991, Gese et al. 1996a). Studies of coyote-lagomorph population cycles, where hares comprise a significant portion of the coyote diet, have demonstrated that during times when snowshoe hare (Lepus americanus) or black-tailed jackrabbit (L. californicus) numbers decline, coyote numbers decline (Clark 1972, Todd et al. 1981, Wagner 1981, Knowlton and Stoddart 1992, O'Donoghue et al. 1997). The mechanism for those declines was reduced ovulation rates and litter sizes, and a decrease in the percentage of adult and yearling coyotes that bred (Todd et al. 1981, Todd and Keith 1983). Food abundance also influences coyote numbers through its affect on dispersal of pups in winter (Gese et al. 1996a). In addition, food shortages can increase mortality (Windberg 1995). Human activities, particularly shooting, trapping, and vehicle collisions cause a high proportion of deaths of coyotes (juveniles and adults), including those in lightly exploited populations (Tzilkowski 1980, Davison 1980, Windberg et al. 1985, Gese et al. 1989, Windberg 1995). Crete and Lemieux (1996) hypothesized this could be a secondary effect related to competition for access to food. Coyote density (i.e., pack size and territory density) is also influenced by food abundance (Harrison 1992). In areas with rigorous winters, when carcass (carrion) biomass is low, coyote pack sizes remain small rates, especially among juvenile coyotes
(Gese et al. 1996a, 1996b). In winters when carcass biomass is greater, more coyotes remain in their social group, and pack size and coyote density increase(Gese et al. 1996a, 1996b).

Food abundance also effects space-use patterns. Mills and Knowlton (1991) examined coyote territory sizes on 2 areas when prey abundance was high and later when it was low. In the Curlew Valley, Utah, coyote territory sizes increased during times of prey scarcity, while on the Idaho National Engineering Laboratory there was no change in territory size during a prey decline, but the percentage of transient coyotes increased. The higher exploitation rate (low adult survival) on the Curlew Valley site may have disrupted some of the "social traditions," allowing territorial adjustments that normally would not occur within short time frames. In addition, there is considerable variation in territory size among packs, presumably due to differences in habitat quality and prey base (Laundré and Keller 1984, Gese et al.1988).

Coyotes exhibit a dominance hierarchy within packs (Camenzind 1978, Gese et al. 1996a) and a land-tenure system of exclusive territories (Camenzind 1978, Bekoff and Wells 1980, 1986, Althoff and Gipson 1981, Bowen 1981, 1982, Messier and Barrette 1982, Andelt 1985, Windberg and Knowlton 1988, Gese et al. 1996a) which serve to mediate coyote numbers as social groups partition the landscape in relation to available habitat and food resources (Knowlton and Stoddart 1983, Gese et al. 1988, Knowlton and Gese 1995). Social dominance among members of resident packs can influence access to clumped food resources, such as ungulate carcasses (Gese et al. 1996a, 1996b). Older, experienced pack members are also more successful hunters of both large prey (Gese and Grothe 1995) and small mammals (Gese et al. 1996c). In addition, dominant individuals with access to carcasses are less likely to disperse (Gese et al. 1996a). Consequently, dominance and territoriality play an important role in regulating coyote numbers. The acquisition of a territory is important because territorial individuals are more apt to survive, have more breeding opportunities, and are more likely to have access to carcasses in winter than transient individuals (Andelt 1985, Bekoff and Wells 1986, Gese et 
al. 1989, 1996a, 1996b). Non-breeding individuals of a pack could be considered surplus, but comprise a significant portion of populations (Gese et al. 1996a).

\section{Effects of Exploitation on Demographics of Coyote Populations}

There have been few detailed studies of unexploited coyote populations (populations in which people do not remove animals) and demographic parameters are frequently omitted, but compared to exploited populations, some demographic differences are emerging (Andelt 1985, Crabtree 1988, Gese et al. 1989, 1996a, Windberg 1995, Windberg et al. 1997a). Unexploited coyote populations typically have older age structures (Fig. 4), high adult survival rates, low reproductive rates (especially among yearlings), and low recruitment into the adult population (Andelt 1985, Windberg et al. 1985, Crabtree 1988, Gese et al. 1989, 1996a, 1996b, Windberg 1995). Such populations may have larger packs or social units depending on available food. Under heavy exploitation, populations are characterized by younger age structures, lower adult survival rates, increased percentages of yearlings reproducing, increased litter size, and relatively small packs (Gier 1968, Knowlton 1972, Berg and Chesness 1978, Davison 1980, Andelt 1987). Although litter sizes may increase in response to reduced coyote density (compensatory reproduction), this is likely a response to reduced competition for food (Andelt 1987, 1996) or breeding among younger females. Mean litter size in an unexploited coyote population in Yellowstone National Park increased over 3 years in response to increased availability of ungulate carcasses during winter (Gese et al. 1996a, 1996b).

\section{Seasonal Fluctuations in Coyote Abundance}

Coyotes are territorial year-round, living in summer where they can survive in winter (Weaver 1979, Gantz 1990, Shivik et al. 1996). Hence territory density remains relatively constant, basically changing only with long-term changes in food base. On the other hand, the size and structure of coyote packs, and hence populations, change seasonally. Births, deaths, and dispersal all have

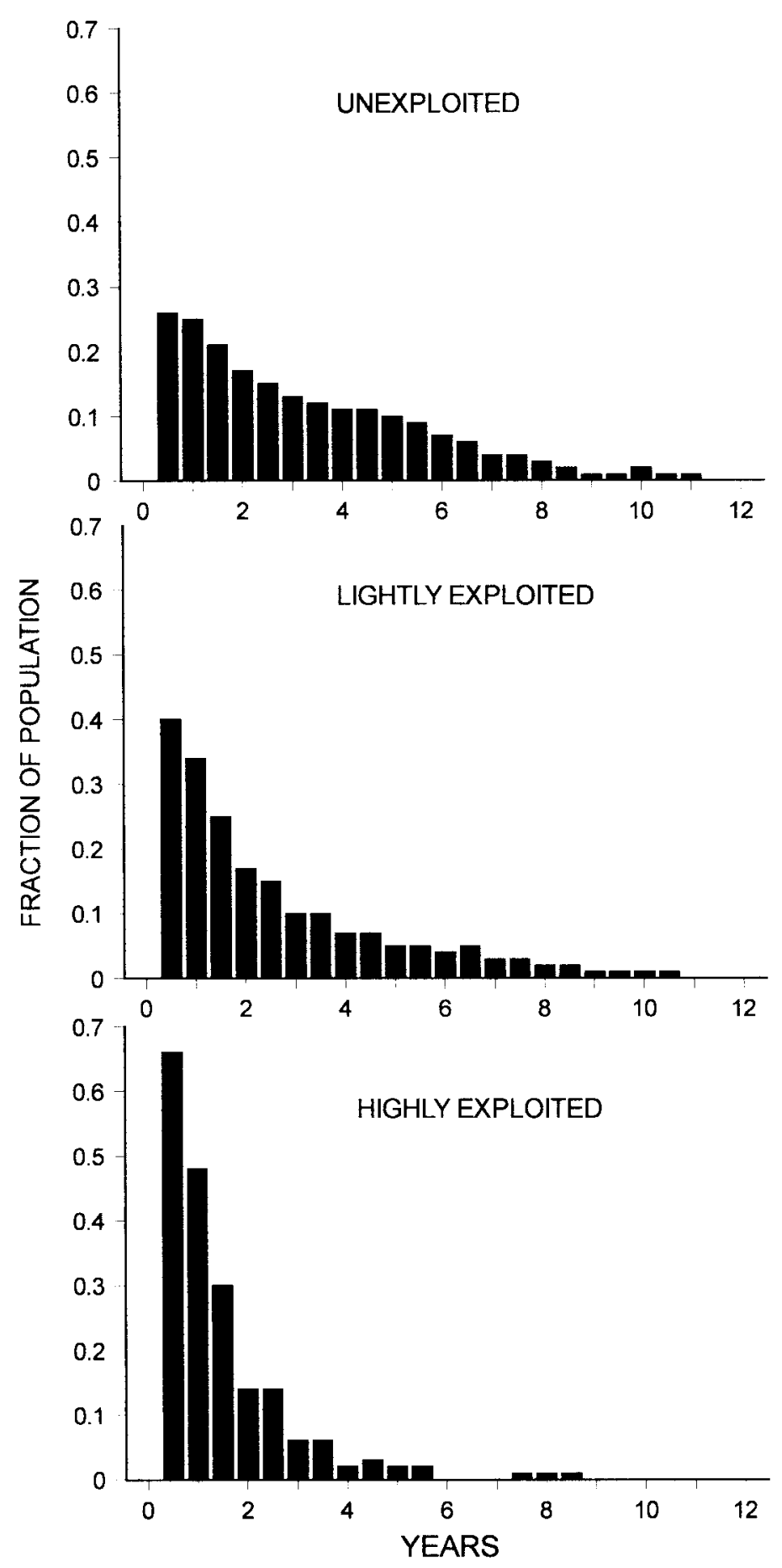

Fig. 4. One-year running means of the age structures of unexploited $(n=4)$, lightly to moderately exploited $(n=7)$, and highly exploited $(n=3)$ coyote populations. Data from Knowlton (1972), Knudsen (1976), Davison (1980), Tzilkowski (1980), Crabtree (1988), and Gese (unpubl. data).

seasonal patterns (Knowlton 1972, Bekoff and Wells 1986, Gese et al. 1996a). The density of coyote populations changes with a pulse, or increase in density, during the whelping season as litters are born, followed by a gradual decline as pups die or disperse and asso- ciate pack members leave during winter (Knowlton 1972, Davison 1980, Gese et al. 1996a). When food resources are favorable, pack sizes may remain high over winter (Gese et al. 1996a, 1996b), but only within the limitations established by the available food. Territory 
density typically remains relatively stable, changing only with long-term changes in the prey base. Concurrently, seasonal patterns in births, deaths, and movements, as mediated by available food, affect the size of coyote packs, and hence coyote density.

\section{Coyote Depredations on Livestock}

The amount of damage producers attribute to coyotes can be a volatile and contentious issue. Some people claim few or no depredations actually occur and accuse producers of grossly exaggerating loss estimates. In contrast, producers indicate losses caused by coyotes can be serious and threaten the economic viability of their enterprises. There have been a series of reviews documenting the economic importance of livestock depredations (Caine et al. 1972, Balser 1974, Gee et al. 1977, U.S. Fish and Wildlife Service 1978). Wagner (1988) provided one of the more comprehensive reviews of the topic.

The economic value of livestock lost to predators has been reported as \$19-38 million to sheep producers in 1977 (U.S. Fish and Wildlife Service 1978), \$75-150 million among lambs, ewes, and calves in 1980 (Wade 1982) and $\$ 83$ million for sheep and lambs in 1987 (Terrell 1988). More recently, Connolly (1992) compared predation loss estimates for sheep and goats among 3 reports (Pearson 1986, General Accounting Office 1990, U.S. Department of Agriculture 1991) and assessed reasons for the vastly different estimates in losses reported and the economic values involved. In part, variability was attributed to differences in the scope of the studies, different assumptions regarding stock inventories, inclusion or exclusion of pre-docking losses of lambs, use of different assumptions and procedures in compiling the loss data, and different monetary values assigned to animals lost. These 3 studies dealt only with direct losses and did not include indirect costs incurred by the livestock industry, or consumers, associated with predation, including costs of intensified husbandry practices, stock replacements, depredation control efforts, contributions to control agencies, and increased prices resulting from reduced supplies (Connolly 1992).

The varied nature of the sheep and goat industries, including size of individual enterprises, differing intensities of husbandry, and various environmental circumstances within which producers operate, makes any simplistic assessment of losses and loss patterns misleading. The number of sheep in the U.S. has declined over $75 \%$ in the past 50 years (Wagner 1988). By 1991, the number of sheep in the U.S. was estimated at 11.17 million, with numbers declining to 8.46 million by 1996 (U.S. Department of Agriculture 1997). In $1974,35 \%$ of the producers had fewer than 25 ewes each and accounted for only $2 \%$ of the sheep in the west (U.S. Fish and Wildlife Service 1978). At the same time, $6 \%$ of the producers had more than 1,000 ewes each, and accounted for over $55 \%$ of the sheep. This variability among producers poses important problems in portraying loss patterns, because there is little information regarding the degree to which individual producers stay within the same portion of the loss spectrum from year to year. Depicting losses based upon accumulated experiences of individual producers exaggerates the importance of smaller producers and minimizes the role of larger producers with the preponderance of sheep. In contrast, basing losses on numbers of sheep may reasonably depict the overall impact of predators upon the sheep population, but may distort the impact on individual producers, especially the smaller ones.

\section{Generalizations about the Magnitude of Losses}

Three major types of studies have been used to assess the magnitude of coyote predation upon sheep: (1) studies where research personnel monitored flocks to account for missing sheep and lambs, (2) producer interviews, and (3) questionnaires mailed to producers or telephone surveys soliciting responses. Advantages and biases associated with each type of study are discussed by Wagner (1988). Field studies should provide the best estimate of losses but do not account for, nor identify, all causes of loss. They are costly in terms of time and resources, and thus have only been used in the context of a few research studies. Interviews with producers are also labor intensive, but larger samples can be accrued. Data obtained, however, are subject to the degree to which producers locate missing animals and accurately identify and report causal agents. Mailed questionnaires or telephone interviews provide the largest amount of information for the time and effort expended but are subject to the same biases as interview responses, with additional biases associated with non-responders. As a result, predation loss estimates vary considerably, as does the degree to which the results can be generalized among sheep areas of the country.

In biologically monitored situations where there were organized depredation control efforts, losses of sheep to coyotes typically range between $1.0-6.0 \%$ for lambs and $0.1-2.0 \%$ for ewes (U.S. Fish and Wildlife 1978). In situations where producers were reimbursed for their losses in lieu of predator control efforts (e.g., Henne 1975, 1977, Brawley 1977, Munoz 1977, McAdoo and Klebenow 1978, Delorenzo and Howard 1976, O'Gara et al. 1983), losses to coyotes were typically higher, ranging from $12-29 \%$ of lambs and $1-8 \%$ of ewes. Data from various questionnaire surveys suggest lower average loss percentages, ranging from $1-5 \%$ for lambs and $0.1-2.5 \%$ for ewes (U.S. Fish and Wildlife Service 1978), but neither the type nor intensity of control measures was identified. The latter samples a wider portion of the sheep industry and, therefore, may be a better overall estimate, but also represents inclusion of many small producers with more intensive management programs and relatively lower losses.

While the foregoing provides an overview of losses of sheep and lambs to coyotes, losses were typically not distributed equally among sheep producers. Balser (1974) and Gee et al. (1977) indicate about half of producers report $<5 \%$ loss of sheep to coyotes, a quarter report $5-10 \%$ loss, one in 10 report losses of $10-15 \%$, and the remainder report losses $>15 \%$ of their flocks. Because the consistency with which individual sheep management units recur within the same portion of the loss spectrum has not been studied, it currently is not practical to use these extensive data sets to assess the degree to which environmental conditions, husbandry practices, and preda- 
tor management programs contribute to the loss patterns. Also, differences in loss rates could be attributable, in part, to the efforts that producers make in accurately assessing the mortality agent (i.e., confirmation of a coyote kill via necropsy).

\section{Factors Influencing Depredation Rates upon Sheep}

Various factors influence coyote depredation rates on sheep, including: breed of sheep, sheep management practices, coyote behavior, environmental factors, and depredation management programs. Sheep have been selectively bred for thousands of years to produce animals that are tractable and suited to particular husbandry techniques, geographic regions, environmental conditions, and cultural requirements, as well as providing desirable characteristics in food and fiber. Changes in animal size and behavior patterns occurred coincident with other developments. Differences in group cohesiveness, sociality, grazing dispersion, attentiveness, and maternal protection may affect vulnerability among breeds. Potentially, husbandry practices may be more important. Confinement, use of predator fences, and shed lambing are practices that can reduce losses. Any reduction in losses, however, is generally achieved at a cost, with many techniques more amenable to small operations than large. Shed lambing is practiced by some large operators with increased lamb survival offset by higher investments in facilities and labor and is used primarily where supplemental feeds are available. Frequently this practice defers predation for 2-3 weeks until the animals return to open pastures and ranges. There may also be a difference in predation risk between pastured versus roving bands of sheep on the range. Theoretically, roving bands of sheep would be exposed to multiple territories of coyotes that may kill sheep, thus increasing predation risk, while pastured sheep would only be exposed to the resident coyotes occupying territories which overlap the sheep pasture (Sacks 1996).

Gluesing et al. (1980) examined behavioral characteristics of sheep to identify characteristics that might be associated with animals within a flock that were most apt to be killed by coyotes. Lambs with impaired mobility, lambs of ewes with impaired mobility, lambs without ewes, lambs displaying aberrant behavior, and lambs that were more active than others were more likely to be killed. Lambs newly introduced to a flock were more likely to be killed than lambs well-integrated into the social structure of flocks; a finding supported by Blakesley and McGrew (1984). It appears that factors which tend to place lambs on the periphery of flocks increase their chances of being killed. Scrivner et al. (1985) indicated that lambs from multiple births had a higher probability of being lost than lambs of single births, although they were unable to specifically assign predation as the cause of loss.

Two aspects of coyote biology warrant consideration: coyote abundance and coyote behavior and learning. Are depredations directly related to coyote abundance? The literature provides information on both sides of the issue. Sheep losses in an area in south-central Idaho were closely related to coyote density, which fluctuated in synchrony with jackrabbit abundance (Stoddart, unpubl. data). In contrast, small sheep flocks in south Texas survive in the midst of some of the highest coyote densities known (Knowlton and Gese 1995). Behavioral differences among coyotes may influence their likelihood to kill. This suggests not all coyotes kill sheep, or that individuals will kill sometimes and not at other times. Many coyotes are never exposed to sheep (Wagner 1988). In some cases, coyotes do not develop sheep-killing behaviors, even when coerced under pen conditions (U.S. Fish and Wildlife Service 1978, Timm and Connolly 1980). Several studies in California (Conner 1995, Shivik 1995, Sacks 1996, Shivik et al. 1996) report numerous radio-collared coyotes in the vicinity of sheep with few, if any, recorded losses of lambs. In these studies, most confirmed coyote kills were directly attributable to predation by breeding, territorial coyotes while other coyotes appeared to be innocuous with regard to depredations. In another study, 6 of 11 coyotes removed by aerially gunning on 4 ranches in Montana showed evidence of having depredated sheep (Connolly and O'Gara 1987, Connolly 1988). Similarly, in an unexploited coyote population, Windberg et al. (1997b) noted $65 \%$ of the coyotes exposed to a herd of goats fed upon them even though the goats were present for only 21 days. It is not known how many of these coyotes were involved in actually killing the goats, but $>40 \%$ of the kids in the herd were killed.

The roles of motivation and learning in coyote depredations have not received adequate attention. Coyotes feed principally on small and mediumsized prey, such as rodents and rabbits, but they do learn to kill and feed on larger prey. Till and Knowlton (1983) demonstrated that provisioning young is an important motivation for territorial coyotes to switch to killing lambs. Interestingly, this behavior is reversible because when the coyote pups were removed, the adults responsible for the depredations usually stopped killing sheep. In contrast, territorial coyotes at the Hopland Field Station, Calif., frequently start killing lambs soon after they become available in December and January, well outside the normal puprearing season (Conner 1995, Sacks 1996). Evidence is accumulating among several canid species suggesting the alpha pair of territorial social groups, especially the males, are the principal actors when killing large prey (Peterson 1977, Mech 1988, Gese and Grothe 1995, Sacks 1996). Understanding these parameters has important implications for the development of more benign and selective depredation control techniques and programs.

Affect of Prey Abundance upon Depredation Rates-Coyote diets, and their associated predation patterns, shift when abundance of one or more prey species change (Hoffman 1979, Hamlin et al. 1984). Some authors (McAdoo 1975, Guthery 1977, Kauffeld 1977, Gober 1979) have found these concepts also apply, to some degree, to coyote predation on sheep (i.e., coyote predation rates on sheep are inversely related to abundance of natural prey). Most of these studies involved seasonal or shortterm shifts in prey abundance and did not consider the potential numerical response of coyote populations as a result of long-term changes in prey abundance. Long-term availability of prey is one determinant of coyote density (Clark 1972, Knowlton and Stoddart 1983, Knowlton and Gese 1995), and there is evidence of a positive association between coyote density and predation losses of sheep (Wagner 1988). A 6-year study in Idaho (Stoddart, unpubl. 
data) found predation rates on sheep increased in direct proportion to changes in coyote abundance, which responded to changes in the abundance of jackrabbits. The increase in coyote density was believed to be due to increased pack size. Whether the alpha pair increased predation on sheep in response to increased pack size (i.e., increased competition), or associate pack members also killed sheep and thus increased overall depredation rates, is unknown. In addition, there was a temporary, but dramatic escalation of depredation on sheep when the hare population collapsed and coyotes had no alternative food source.

Other Considerations-Only recently have food-caching behaviors among coyotes been recognized and documented, although they now appear to be quite common (Weaver 1977, Windberg et al. 1997b). Caching typically occurs when more food becomes available than a coyote, or group of coyotes, can consume at a given time. The degree to which food-caching is a factor in the failure to locate missing livestock (e.g., Scrivner et al. 1985), especially small lambs and kids, is not known but caches of complete jackrabbits, and heads, shoulders, and hind quarters of 15-20 pound lambs and kid goats are well documented (Stoddart, unpubl. data; Windberg et al. 1997b).

There is speculation (e.g., Wilkinson 1996) that coyote populations not subject to human-induced mortality might pose less risk to livestock than populations manipulated to reduce coyote abundance. The underlying rationale suggests undisturbed coyote populations have fewer and smaller litters, resulting in reduced motivations to feed pups, and translate into reduced depredations on livestock. While there is evidence suggesting litter sizes might change (Crabtree 1988, Knowlton and Gese 1995, Windberg 1995, Windberg et al. 1997a), evidence that fewer litters would be produced is meager; simultaneous measures of both reproductive rates and population size from populations in similar environments would be needed to clarify this issue. To date, this has not been done. Low productivity among unexploited coyote populations has been reported (Knowlton 1972, Crabtree 1988, Gese et al. 1989, Windberg et al. 1997a). In contrast, Windberg et al. (1997b) reported $41 \%$ of 34 kid goats were killed by coyotes within 3 weeks of the time they were released within an unexploited coyote population with very low reproductive rates (Windberg et al. 1997a). Although which coyotes killed goats was not determined, both territorial and transient, as well as males and females fed on the goats. In addition, Sacks (1996) and Conner (1995) reported extensive predation on lambs in California during December and January when coyote pups were not present, indicating that provisioning pups is not the only motivation for coyote predation on lambs.

\section{Depredation Control}

Protecting livestock from coyote depredations is a complex endeavor, with each case frequently requiring a unique assessment of the legal, social, economic, biological, and technical aspects. The general philosophic approach outlined by Slate et al. (1992) for formulating procedures to resolve individual problems is well-recognized. Successful resolution of wildlife conflicts involves the anticipated efficacy, selectivity, and efficiency of various management approaches, including both corrective and preventive techniques. Perennial patterns of depredations are also involved. Programs and procedures that are more benign in their affects on wildlife, including coyotes, should be preferred to those creating greater perturbations.

The variety of motivations, circumstances, and conditions in which predation occurs precludes the likelihood any one procedure will effectively prevent or resolve most depredation problems. Consequently, a variety of tools and applications have been developed to fit different situations. Fall (1990) and Andelt (1996) identified many of the techniques available for reducing coyote depredations, from deterring problems to removing individual animals or populations posing risks to other human endeavors. The intent here is to examine data regarding the efficacy of various techniques and factors that appear to affect their usefulness.

\section{Non-Removal Techniques}

A diverse array of procedures have been used to create physical barriers between coyotes and livestock or to deter coyotes from attacking livestock (Linhart 1984a, Wagner 1988, Fall 1990, Green et al. 1994). Most nonremoval depredation control procedures fall within the operational purview of livestock producers. While there are reports of success with many such methods, failures are common, few have been subjected to experimental tests, and none have proven universally successful. Additional information is needed to clarify the factors that influence the success of individual techniques.

Livestock Husbandry PracticesAlthough various livestock management practices have been repeatedly suggested as means of reducing depredation losses (Robel et al. 1981, Wagner 1988), few have been systematically scrutinized under controlled conditions to determine their efficacy, costs, and benefits. Some of the more frequently mentioned practices include: (1) confining or concentrating flocks during periods of vulnerability (e.g. at night or during lambing), (2) using herders, (3) shed lambing, (4) removing livestock carrion from pastures to retard food recognition by coyotes, (5) synchronizing birthing to reduce the period of maximum vulnerability, and (6) keeping young animals in areas with little cover and in close proximity to human activity. These procedures generally require additional resources and efforts, and frequently only delay the onset of predation, or have undesirable side effects. For example, penning animals at night requires additional effort and frequently creates spot deterioration of pastures and ranges. Similarly, shed lambing decreases the mortality of lambs from many causes but requires additional labor as well as a ready and affordable supply of feed. For these procedures to be effective, producers must develop specific strategies tailored to their own situations, recognizing that definitive economic advantages may be difficult to demonstrate.

Fencing-Various configurations of fencing can exclude or deter coyote use of specific areas (de Calesta and Cropsey 1978, Linhart et al. 1982, Shelton 1984, 1987, Nass and Theade 1988), but few can be identified as being "coyote-proof" because coyotes learn to dig under or jump over fences. Installation costs usually preclude the use of effective fences except where high value commodities are concentrat- 
ed in small areas. The dispersed nature and low economic density associated with most sheep grazing in the semi-arid regions of the western United States makes fencing an impractical procedure for preventing depredations. In addition, fencing that denies access to coyotes will likely inhibit movements of other wildlife species.

Frightening Devices-Electronic devices that periodically emit bursts of light or sound have been shown to deter coyote predation on sheep in both fenced pastures (Linhart et al. 1982, Linhart 1984b, Linhart et al. 1984) and on open range situations (Linhart et al. 1992). Other studies (Bomford and O'Brien 1990, Koehler et al. 1990) report benefits from such devices are variable and short-lived. Linhart et al. (1992) argued that habituation by coyotes can be retarded if the devices are used in appropriate numbers, moved periodically, and programmed to vary the temporal pattern of multiple stimuli. Use of such frightening devices are not widespread, partially because use of sirens and strobe lights at night near people is not acceptable.

Guard Animals-Use of guard animals appears to be a promising way of encouraging coyotes to avoid livestock. Dogs, llamas, and donkeys or mules are most commonly mentioned as livestock guards. The most extensive evaluations have been with dogs (Linhart et al. 1979, Coppinger et al. 1983, Black and Green 1984, Green et al. 1984, Green and Woodruff 1983, 1987). While dogs appear effective in some situations (e.g. Linhart et al. 1979), they are not in others (Timm and Schmidt 1989, Conner 1995). Reasons for this are not fully understood, but sheep can be very difficult to protect when they are in large flocks, dispersed over rough terrain, and where there is thick cover for coyotes. In addition, training and close supervision of the dogs seem important to success. Some poorly trained or supervised guard dogs have killed sheep and lambs, harassed or killed wild animals, and threatened people that intruded into the dogs' domains (Timm and Schmidt 1989). In instances where guard dogs are ineffective, their presence frequently precludes that use of other techniques (e.g., traps, snares, M-44's) or reduces the efficiency of others (e.g., calling and shooting).

Llamas may be more practical for many situations (Powell 1993). They can be kept in fenced pastures, do not require special feeding programs, are usually tractable, and have a relatively long working life compared with dogs. Evaluations currently in progress are promising (Cavalcanti 1997, Meadows 1999) but further study of the circumstances in which llamas are effective is needed and the degree to which coyotes may habituate to their presence needs to be assessed. To date, there have been no systematic field studies of the behavior of coyotes toward guard animals. Radioed coyotes have been found in close proximity to sheep bedding grounds and the attending guard dog (Conner 1995). One hypothesis is that although guard animals may not deter coyotes from grazing areas, they may change the coyotes' agenda when in those areas.

Repellents and Learned AversionsAt present, there are no commercially available repellents that effectively deter coyote predation. A variety of noxious gustatory, olfactory, and irritating products have been tested in captive situations. A few show promise for reducing food consumption. These include pulegone, cinnamaldehyde, and allyl sulfide (Hoover 1996). While repellents, including quinine hydrochloride and capsaicin show promise in discouraging coyote damage to inanimate items like irrigation hoses (Werner et al. 1997), there is meager information demonstrating these substances deter predation (Lehner 1987). Available evidence suggests attacks continue despite presence of these materials, although different sites of attack are sometimes employed (Burns and Mason 1997).

Conditioned taste aversion, using lithium chloride, to reduce coyote depredations on sheep received much scientific attention in the 1970's and 1980's. Results of studies have been equivocal, with some investigators reporting success (Gustavson et al. 1974, Ellins and Martin 1981, Gustavson et al. 1982, Forthman-Quick et al. 1985a, 1985b), while others were either unable to replicate those research findings or to make them effective in field situations (Conover et al. 1977, Burns 1980, Bourne and Dorrance 1982, Burns 1983, Burns and Connolly 1985). In pen tests, coyotes frequently distinguished between treated and untreated baits, avoided the former, and did not general- ize aversion of baits to live prey (Burns and Connolly 1980). While lithium chloride reduces consumption, it does not deter predation. There are indications that positive reinforcement from prior predatory acts may interfere with acquisition of associations between sheep ingestion and sickness (Conover et al. 1977, Burns 1980). Ten years after the most extensive field trials involving use of lithium chloride (Gustavson et al. 1982, Jelinski et al. 1983), a survey of the same sheep producers revealed that while $54 \%$ of the original participants considered the technique "successful" or "somewhat successful," only one still used it (Conover and Kessler 1994). In addition, only 3 of 47 randomly selected producers in that region had ever used the technique and only one used it the year prior to the survey (Conover and Kessler 1994). Available evidence suggests conditioned taste aversions, as attempted to date, are either ineffective or unreliable methods of depredation control.

Reproductive Interference-Initial attempts to influence the reproductive process of coyotes with chemical sterilants assumed reduced reproduction would reduce coyote population levels and that fewer coyotes would result in fewer depredations (Balser 1964). This procedure was appealing because it attempted to resolve depredations without killing coyotes. Trials with diethylstilbesterol indicated reproduction could be thwarted (Balser 1964, Linhart et al. 1968), but timing was critical and the approach was impractical without effective bait delivery systems (see Kirkpatrick and Turner 1991 for a review). In the mid-1970s, registration of any material with potentially broad spectrum effects in field applications appeared unlikely and research development on this substance was curtailed. Currently there is renewed interest in reproductive inhibition using immunocontraception (Miller 1995, DeLiberto et al. 1998). Although such techniques are presently unavailable for coyotes, it is anticipated that species specific materials with reversible effects may become available.

An alternate paradigm for interfering with reproductive processes involves sterilizing territorial, breeding coyotes in vicinities where chronic depredations occur. This strategy is predicated on research indicating depredations can be 
reduced by removing pups of depredating coyotes (Till and Knowlton 1983) and assumes: (1) territorial breeders are the principal killers of livestock; (2) they will continue to maintain territories while sterile; and (3) depredations in some areas are linked to the presence of pups. The first assumption is supported by Sacks (1996); and the second appears likely on the basis of pen studies (Zemlicka 1995). However, research in north-coastal California, where depredations peak during a lambing season which is out-of-phase with pup-rearing (Scrivner et al. 1985, Conner 1995, Sacks 1996),suggests that presence of lambs, rather than pups, may also be an important determinant of predation patterns.

Although coyote predation can be deferred by non-removal techniques, coyotes frequently habituate, or adapt, to the presence or use of such procedures. This probably happens more quickly when alternative foods are limited or when energy demands are high (e.g., during pup rearing). In some instances, procedures which rely on fright or avoidance appear adequate, at least on a temporary basis. In others, coyotes continue to investigate, and kill livestock in the presence of non-removal depredation control techniques. For example, Conner (1995) documented coyotes killing sheep in close proximity to a radiocollared guard dog.

\section{Coyote Removal Techniques}

When depredations can not be stopped effectively and efficiently with nonremoval techniques, removing one or more coyotes may be needed to temporarily reduce risks to livestock. In some instances, removal of 1 or 2 individuals may suffice, and in others, coyote population reduction may be warranted. Factors affecting selection of the specific option(s) include: (1) nature of the problem; (2) presence or absence of historical patterns; (3) relative size of the area involved; (4) season of the year and timing with regard to depredations or anticipated depredations; and (5) the efficacy, selectivity, and efficiency of specific removal methods or procedures. While most non-removal depredation control techniques fall within the purview of livestock producers, most procedures and techniques that rely on coyote removal are relegated to programs administered by wildlife manage- ment agencies due to: (1) the sophistication and technical expertise required; (2) regulatory and accountability concerns; and (3) the need for coordination.

Techniques for Removing Offending Coyotes-Removing individual coyotes responsible for depredations is especially suited to small areas where specific coyotes pose immediate risks. Resolution at this scale is generally corrective in nature (i.e., stopping ongoing depredations) and typically requires the highest levels of skill in depredation control. Calling and shooting, with or without the help of lure dogs, can be a selective means of removing coyotes that kill livestock, particularly during denning and pup-rearing seasons (Alcorn 1946, Coolahan 1990). This procedure is extremely selective for coyotes, with selectivity for individuals responsible for depredations dependent on the accuracy of identifying areas used by them.

Where livestock can be effectively manipulated, Livestock Protection Collars can selectively remove specific coyotes responsible for depredations (Burns et al. 1988, 1996, Connolly and Burns 1990, Connolly 1993, Rollins 1995). These devices are registered by the Environmental Protection Agency (EPA) for use by ranchers in states with approved training and accountability programs. Currently, 7 states have EPAapproved programs, with approvals pending in others. The collars have toxicant-containing pouches that are punctured when coyotes attack the sheep's throat, thereby releasing the poison into the coyote's mouth. This may be the most selective procedure for removing specific coyotes responsible for killing livestock, but it is not always efficient because of the inherent difficulty in anticipating which sheep or lambs are most likely to be killed.

Coyotes causing depredations can be removed with traps, snares, and M-44 devices, but the efficiency of capture and selectivity for coyotes in general, and offending individuals in particular, is usually lower. Most depredations can be attributed to territorial, dominant coyotes (Till and Knowlton 1983, Sacks 1996), with depredations usually occurring within the territorial boundaries of the animal(s) responsible (Blejwas, unpubl. data). Unfortunately, coyotes are less vulnerable to capture devices when encountered within familiar areas
(Harris 1983, Windberg and Knowlton 1990, Windberg 1996), making removal of offending individuals difficult (Conner 1995, Sacks 1996) and the risk of capturing coyotes from surrounding areas greater (Hibler 1977, Windberg and Knowlton 1990). In addition, persistent exposure to capture devices can reduce their effectiveness (Andelt et al. 1985, Brand et al. 1995).

Coyote Population Reduction Programs-There are a variety of situations where reducing the number of coyotes is desired, including situations where coyotes pose a risk to other wildlife species (Guthery and Beasom 1977, Connolly 1978, Smith et al. 1986, Teer et al. 1991, Cypher and Scrivner 1992, Henke 1995), when spread of infectious diseases need to be curtailed (Clark et al. 1994, Clark and Wilson 1995), and when more benign depredation control techniques are ineffective. Meeting such objectives usually involves removing significant portions of the coyote population. However, which coyotes and how many coyotes to be removed, are recurring problems with non-selective removal programs. The resilience of coyote populations dictates that the size of the area involved (Stoddart et al. 1989), the intensity and persistence of effort, timing of removal with respect to vulnerability of prey, as well as normal demographic processes of coyotes, must be considered. Effecting removals as close as practical to the anticipated risks, both in time (Knowlton 1972) and proximity (Stoddart et al. 1989), is important. Even under the most severe removal programs, repopulation by coyotes can be expected within months (Beasom 1974) or 2-3 years (Connolly and Longhurst 1975, Connolly 1978, 1995). Repopulation is particularly fast on small areas, such as individual ranches or pastured sheep operations. Effects of population reduction programs are most persistent when efforts are conducted over large areas (Stoddart et al. 1989) and occur after the dominance and territorial patterns of coyotes are set for the coming breeding period and immediately prior to whelping. This timing reduces the possibility of other coyotes repopulating the area, establishing pair-bonds, and producing offspring within the current breeding season (Knowlton 1972, Connolly 1978, 1995). One of the more effective programs of population reduc- 
tion occurred on the Edwards Plateau of Texas where coyotes were almost eradicated between the 1920's and 1950's (Nunley 1995). That effort was aided by a pervasive distribution of sheep and goats in the area, extensive use of netwire fencing that helped identify coyote travel patterns, and population reduction programs around the perimeter that reduced immigration. Deteriorating netwire fences, fractionation of the grazing areas (and hence the coyote reduction program), and reduced coyote control efforts around the periphery of the Plateau likely contributed to a resurgence of coyotes since 1970 (Pearson and Caroline 1981, Nunley 1995).

Depredation management in the form of preventive control (Wagner 1988) is a preemptive removal of coyotes from areas with historic patterns of depredations, frequently where other types of depredation control are not feasible or effective, or where coyote depredations are a perennial and chronic problem. It is predicated partially upon the assumption that livestock losses are directly related to the numbers of coyotes present, and that removal of coyotes will produce a proportionate reduction in depredations. This is consistent with the observation of a positive linear relationship between coyote abundance and sheep depredations (Stoddart, unpubl. data). Another study indicated that over a 7-year period the depredation rate on sheep on the Honn Ranch, Wash., was inversely related to the number of coyotes removed (Stream 1976). In contrast, examination of a 12-year data set from a California sheep ranch (Conner et al. 1998) found that killing remained high in some years despite corrective removal of coyotes and there was no correlation between the numbers of coyotes removed and the numbers of sheep subsequently killed. Thus, a fundamental question remains: does partial, nonselective removal of coyotes effectively reduce depredations on sheep? Since removal of all coyotes from an area will, temporarily, eliminate coyote predation, the question really relates to the theoretical nature of the relationship between coyote removal and depredation rates. Assumptions about the duration of the effect are also involved.

Preventive depredation control efforts on mountain pastures, particularly winter removal of coyotes from summer grazing allotments, has been criticized because of the 5-6 month lapse between coyote removal and anticipated losses during the ensuing summer grazing season. Examining coyote movements in montane areas, Gantz (1990) found that territorial coyotes used the same areas in winter as they do in summer; a finding similar to that of Weaver (1979) and Shivik et al. (1996). Hence, animals removed in winter would likely include animals living and rearing pups in those areas the following summer. Wagner (1997) evaluated aerial hunting on mountain grazing allotments where coyotes were removed in January and February, when coyotes were more vulnerable due to environmental conditions (snow cover), and documented the subsequent sheep losses during summer following winter aerial hunting. On allotments receiving aerial hunting (treated), lamb losses to all causes declined $25 \%$, while lamb losses to all causes declined $6 \%$ on untreated allotments. The number of lambs confirmed to be killed by coyotes declined by $7 \%$ on treated allotments, whereas lambs killed by coyotes increased $35 \%$ on allotments receiving no aerial hunting. Confounding variables in this study were the relatively high sheep losses on the control and treatment areas, as well as the degree of coyote removal on all the grazing allotments prior to the study.

Demographic Consequences of Coyote Population Reduction-Because coyote populations are dynamic and resilient, effects of coyote removal are ephemeral, with normal demographic responses attempting to return the population to levels consistent with available food and habitat conditions. These responses include: recolonization from adjacent areas, increased breeding among younger females, increased litter size, and increased survival rates. The speed with which populations return to "normal" levels is dependent upon the size of area involved and the intensity of the removal program. On small management units, immigration of non-territorial coyotes from surrounding areas should occur rapidly, probably within weeks or months. On larger areas, recruitment would come from immigration as well as increased productivity by surviving coyotes. A temporary increase in juvenile survival could also be expected. Although we would expect higher reproductive rates, speculations that more pups might be recruited into a reduced population, and thus increase population density beyond the preremoval level, are unwarranted because competing rates of change are involved (i.e., any increased reproductive rate would be applied to a smaller population). At this point, the relationship between the degree of reduction and increased productivity remains conjectural. Similarly, increased survival of coyote pups could be expected, but expectations that population levels would exceed those dictated by available food resources are unrealistic.

The effectiveness of coyote population reduction on small management units (Stoddart et al. 1989) or with inadequate intensities of effort are apt to be disappointing (Beasom 1974). Including a buffer zone around the primary reduction area (Stoddart et al. 1989) could enhance the effectiveness of removal programs because it would provide vacant territories to absorb some dispersing coyotes that might otherwise infiltrate the primary protection zone (Knowlton 1972, Davison 1980). However, establishing a buffer zone removes territorial animals from adjacent areas that are probably "staying home" and not involved in the localized depredation problem (Sacks 1996). Establishing a buffer around protection zones may be neither socially or politically acceptable as well. Depredation relief resulting from a coyote population reduction program should be considered transitory, unless the removal program is maintained. Decisions about the timing and intensity of such efforts should incorporate information about the period that protection is needed, when populations are vulnerable, as well as the phenologies associated with coyote biology.

\section{Synthesis}

Some coyotes kill domestic stock and persistent depredations can place some livestock producers in economic jeopardy. Various techniques can prevent or curtail predation on livestock but none are universally effective. Most techniques used to prevent coyote depredations do not involve removing coyotes and typically involve activities relegated primarily to livestock producers, while removing coyotes to solve depredation problems is typically more effectively done by wildlife management personnel. 
Unfortunately, the dominant territorial animals most likely to cause depredations are also more difficult to remove. Differences among depredations, the circumstances in which they occur, and the behaviors and motivations among coyotes makes simple resolution of problems unlikely.

Typically, nonlethal techniques are initially attempted by livestock producers when they experience depredations by coyotes. Some success can be achieved with the use of fencing on small pastures, improved husbandry practices (e.g., shed lambing, having shepherds present) on small and large operations if economically feasible, or guard animals on larger fenced operations where open habitat allows guard animals to detect coyotes. Guard dogs frequently limit the use of other techniques (e.g., trapping, calling and shooting) because techniques used to attract coyotes also attract guard dogs. Llamas appear effective, particularly when placed singly with stock (i.e., 2 llamas may ignore the sheep) and in open habitat allowing them good visibility and less concealment for coyotes. These approaches can be implemented with some success, but require additional labor and expense to the producer. Although they may be initially effective, frightening devices become ineffective as coyotes habituate to them. At present, aversive conditioning appears to be a nonviable option because, while it stops the consumption of food, it apparently fails to prevent predatory motivations. Currently, there are no effective repellents that deter coyote predation, only consumption or avoidance of inanimate objects. Presently, reproductive intervention to modify the predatory behavior of coyotes holds promise as a technique and warrants continued investigation. This technique may work well in the intermountain west where sheep are a seasonal and temporary food source for coyotes. However, in areas where sheep are perpetually present (e.g., coastal California, Texas), sheep become part of the prey base and are a year-round food source, with coyote predation not tied to pup production. With regards to the coyotes themselves, it must be remembered that the stimuli for coyotes to chase and kill prey is a strong, powerful, and innate predatory behavior. Nonlethal methods and ideas as to how to modify this instinctive behavior requires careful thought and innovative research.

Lethal removal usually is implemented when nonlethal procedures are impractical or ineffective. Typically, large operations on open ranges resort to lethal control because fencing is impractical and bands are too large to pen at night or for guard animals and shepherds to effectively patrol. Local population reduction can provide temporary relief to sheep operators, but only until the local coyote population compensates for the removals and fills vacant territories. The more focused removals are to the area of depredations, the shorter the duration of the effect. Population reduction as a management option usually requires annual reapplications due to the reproductive capabilities and ease of movement of coyotes (i.e., dispersal of juveniles and presence of transients). A lethal technique that selectively targets offending coyotes killing sheep is the use of Livestock Protection Collars. However, this technique requires state by state authorization (registration) by the EPA and attendant technical training programs. Traditional methods of capture (traps, snares) can potentially remove offending animals, but can be difficult, and remains relatively nonselective. Regulations regarding lethal control and removal of coyotes must be examined prior to implementing such programs; permits may be required for some activities. Four states (Arizona, California, Colorado, and Massachusetts) currently have restrictions on the use of leg-hold traps. Other states (e.g., Arizona, Utah) have specific limits on aerial hunting practices.

Preferred management options should be those that resolve problems efficiently in the least intrusive manner. This requires a careful analysis of each situation; matching biological, legal, social, and economic considerations with an understanding of the merits and limitations of individual techniques.

There is a continued need for research to examine and evaluate the effects of coyote removal and the efficacy of various control techniques in an objective and statistically sound way (i.e., adequate sample sizes and controls). Development of non-lethal methods, as well as lethal methods which target the dominant, territorial coyotes responsible for the depredation problem, are also needed. There is no "magic bullet" tech- nique that can be recommended to solve all depredation problems on livestock. Successful depredation management requires a variety of techniques used in an integrated program. While the controversy surrounding coyote management will remain emotional, political, and subject to debate, the evolution of coyote depredation management is dependent upon sound research and objective data interpretation.

\section{Literature Cited}

Alcorn, J.R. 1946. On the decoying of coyotes. J. Mamm. 27:122-126.

Althoff, D.P., and P.S. Gipson. 1981. Coyote family spatial relationships with reference to poultry losses. J. Wildl. Manage. 45:641-649.

Andelt, W.F. 1985. Behavioral ecology of coyotes in south Texas. Wildl. Monogr. 94:1-45.

Andelt, W.F. 1987. Coyote predation, p. 128-140. In: M. Novak, J. A. Baker, M. E. Obbard, and B. Malloch (eds.), Wild furbearer management and conservation in North America. Ontario Ministry of Natur. Resour. and the Ontario Trappers Assoc.

Andelt, W.F. 1996. Carnivores, p. 133-155. In: P. R. Krausman (ed.), Rangeland wildlife. Soc. Range Manage., Denver, Colo.

Andelt, W.F., C.E. Harris, and F.F. Knowlton. 1985. Prior trap experience might bias coyote response to scent stations. Southw. Natur. 30:317-318.

Balser, D.S. 1964. Management of predator populations with antifertility agents. J. Wildl. Manage. 28:352-358.

Balser, D.S. 1974. An overview of predatorlivestock problems with emphasis on livestock losses. Trans. North Amer. Wildl. Natur. Resour. Conf. 39:292-298.

Bangs, E.E. and S.H. Fritts. 1996. Reintroducing the gray wolf to central Idaho and Yellowstone National Park. Wildl. Soc. Bull. 24:402-413.

Beasom, S.L. 1974. Intensive short-term predator removal as a game management tool. Trans. North Amer. Wildl. Natur. Resour. Conf. 39:230-240.

Bekoff, M. and M.C. Wells. 1980. The social ecology of coyotes. Sci. Amer. 242:130-148.

Bekoff, M., and M.C. Wells. 1986. Social ecology and behavior of coyotes. Adv. Study Behav. 16:251-338.

Berg, W.E. and R.A. Chesness. 1978. Ecology of coyotes in northern Minnesota, p. 229-247. In: M. Bekoff (ed.), Coyotes: biology, behavior, and management. Academic Press, New York, N.Y. 
Black, H.L. and J.S. Green. 1984. Navajo use of mixed-breed dogs for management of predators. J. Range Manage. 38:11-45

Blakesley, C.S. and J.C. McGrew. 1984. Differential vulnerability of lambs to coyote predation. Appl. Anim. Behav. Sci. 12:349-361.

Bomford, M. and P.H. O'Brien. 1990. Sonic deterrents in animal damage control: a review of device tests and effectiveness. Wildl. Soc. Bull. 18:411-422.

Bourne, J. and M.J. Dorrance. 1982. A field test of lithium chloride aversion to reduce coyote predation on domestic sheep. J. Wildl. Manage. 46:235-239.

Bowen, W.D. 1981. Variation in coyote social organization: the influence of prey size. Can. J. Zool. 59:639-652.

Bowen, W.D. 1982. Home range and spatial organization of coyotes in Jasper National Park, Alberta. J. Wildl. Manage. 46:201-215.

Brand, D.J., N. Fairall, and W.M. Scott. 1995. The influence of regular removal of black-backed jackals on the efficiency of coyote getters. S. Afr. J. Wildl. Res. 25:44-48.

Brawley, K.C. 1977. Domestic sheep mortality during and after tests of several predator control methods. M.S. Thesis, Univ. Montana, Missoula, Mont.

Burns, R.J. 1980. Evaluation of conditioned predation aversion for controlling coyote predation. J. Wildl. Manage. 44:938-942.

Burns, R.J. 1983. Microencapsulated lithium chloride bait aversion did not stop coyote predation on sheep. J. Wildl. Manage. 47:1010-1017.

Burns, R.J. and G.E. Connolly. 1980. Lithium chloride bait aversion did not influence prey killing by coyotes. Vert. Pest Conf. 9:200-204.

Burns, R.J. and G.E. Connolly. 1985. A comment on "Coyote control and taste aversion." Appetite 6:276-281.

Burns, R.J. and J.R. Mason. 1997. Effectiveness of Vichos non-lethal collars in deterring coyote attacks on sheep. Proc. Vert. Pest Conf. 17:204-206.

Burns, R.J., G.E. Connolly, and P.J. Savarie. 1988. Large livestock protection collars effective against coyotes. Proc. Vert. Pest Conf. 13:215-219.

Burns, R.J., D.E. Zemlicka, and P.J. Savarie. 1996. Effectiveness of large livestock protection collars against depredating coyotes. Wildl. Soc. Bull. 24:123-127.

Buys, C. J. 1975. Predator control and ranchers' attitudes. Environ. Behav. 7:81-98.

Caine, S.A., J.A. Kadlec, D.L. Allen, R.A. Cooley, M.C. Hornocker, A.S. Leopold, and F.H. Wagner. 1972. Predator control1971-Report to the Council on Environmental Quality and the Department of the Interior by the Advisory Committee on Predator Control. Counc. on Environ.Quality and USDI, Washington, D.C.
Camenzind, F.J. 1978. Behavioral ecology of coyotes on the National Elk Refuge, Jackson, Wyoming, p. 267-294. In: M. Bekoff (ed.), Coyotes: biology, behavior, and management. Academic Press, New York, N.Y

Cavalcanti, S.M.C. 1997. Evaluation of physical and behavioral traits of llamas (Lama glama) associated with aggressiveness toward sheep-threatening canids. M.S. Thesis, Utah State Univ., Logan, Ut.

Clark, F.W. 1972. Influence of jackrabbit density on coyote population change. J. Wildl. Manage. 36:343-356.

Clark, K.A. and P.J. Wilson. 1995. The coyote's role in a rabies epidemic, p. 41-45. In: D. Rollins, C. Richardson, T. Blankenship, K. Canon, and S. Henke (eds.), Coyotes in the southwest: a compendium of our knowledge. Tex. Parks Wildl. Dept., Austin, Tex.

Clark, K.A., S.U. Neill, J. S. Smith, P.J. Wilson, V.W. Whadford, and G.W. McKirahan. 1994. Epizootic canine rabies transmitted by coyotes in south Texas. J. Amer. Vet. Med. Assoc. 204:536-540.

Conner, M.M. 1995. Identifying patterns of coyote predation on sheep on a northern California ranch. M.S. Thesis, Univ. California, Berkeley, Calif.

Conner, M.M., M.M. Jaeger, T.J. Weller, and D.R. McCullough. 1998. Impact of coyote removal on sheep depredation in northern California. J. Wildl. Manage. 62:690-699.

Connolly, G.E. 1978. Predator control and coyote populations: a review of simulation models, p. 327-345. In: M. Bekoff (ed.), Coyotes: biology, behavior, and management. Academic Press, New York, N.Y.

Connolly, G.E. 1988. Aerial hunting takes sheep-killing coyotes in western Montana, p. 184-188. In: USDA Forest Serv. Gen. Tech. Rep. RM-154.

Connolly, G.E. 1992. Sheep and goat losses to predators in the United States. Proc. East. Wildl. Damage Control Conf. 5:75-82.

Connolly, G.E. 1993. Livestock protection collars in the United States, 1988-1993. Proc. Great Plains Wildl. Damage Control Workshop 11:25-33.

Connolly, G.E. 1995. The effects of control on coyote populations: another look, $\mathrm{p}$. 23-29. In: D.Rollins, C. Richardson, T. Blankenship, K. Canon, and S. Henke (eds.), Coyotes in the southwest:a compendium of our knowledge. Tex. Parks Wildl. Dept., Austin, Tex.

Connolly, G.E. and R.J. Burns. 1990. Efficacy of compound 1080 Livestock Protection Collars for killing coyotes that attack sheep. Proc. Vert. Pest Conf. 14:269-276.

Connolly, G.E. and W.M. Longhurst. 1975. The effects of control on coyote populations: a simulation model. Div. Agr. Sci., Univ. California, Davis, Bull. 1872.
Connolly, G.E. and B.W. O'Gara. 1987. Aerial hunting takes sheep-killing coyotes in western Montana. Proc. Great Plains Wildl. Damage Control Workshop. 8:184-188.

Conover, M.R. and K.K. Kessler. 1994. Diminished producer participation in an aversive conditioning program to reduce coyote depredation on sheep. Wildl. Soc. Bull. 22:229-233.

Conover, M.R., J.G. Francik, and D.E. Miller. 1977. An experimental evaluation of using taste aversion to control sheep loss due to coyote predation. J. Wildl. Manage. 41:775-779.

Coolahan, C. 1990. The use of $\operatorname{dog}$ s and calls to take coyotes around dens and resting areas. Proc. Vert. Pest Conf. 14:260-262.

Coppinger, R., J. Lorenz, and L. Coppinger. 1983. Introducing livestock guarding dogs to sheep and goat producers. Proc. Eastern Wildl. Damage Control Conf. 1:129-132.

Crabtree, R.L. 1988. Sociodemography of an unexploited coyote population. Ph.D. Diss., Univ. Idaho, Moscow, Ida.

Crete, M. and R. Lemieux. 1996. Population dynamics of coyotes colonizing the boreal forest of southeastern Quebec. J. Wildl. Res. 1:99-105.

Cypher, B.L. and J.H. Scrivner. 1992 Coyote control to protect endangered San Joaquin kit foxes at the Naval Petroleum Reserves, California. Proc. Vert. Pest Conf. 15:42-47.

Davison, R.P. 1980. The effect of exploitation on some parameters of coyote populations. Ph.D. Diss., Utah State Univ., Logan, Ut.

de Calesta, D.S. and M.G. Cropsey. 1978. Field test of a coyote-proof fence. Wildl. Soc. Bull. 6:256-259.

DeLiberto, T.J., M. R. Conover, E. M. Gese, F.F. Knowlton, R.J. Mason, L. Miller, R.H. Schmidt, and M. Holland. 1998. Fertility control in coyotes: is it a potential management tool? Proc. Vert. Pest Conf. 18:144-149.

Delorenzo, D.G. and V.W. Howard, Jr. 1976. Evaluation of sheep losses on a range lambing operation without predator control in southeastern New Mexico. Final rep. to the U.S. Fish and Wildl. Serv., Denver Wildl. Res. Ctr., New Mexico State Univ., Las Cruces.

Ellins, S.R. and G.C. Martin. 1981. Olfactory discrimination of lithium chloride by the coyote (Canis latrans). Behav. Neural. Biol. 31:214-224.

Fall, M.W. 1990. Control of coyote depredation on livestock - progress in research and development. Proc. Vert. Pest Conf. 14:245-251.

Forthman-Quick, D.L., C.R. Gustavson, and K.W. Rusiniak. 1985a. Coyote control and taste aversion. Appetite 6:253264. 
Forthman-Quick, D.L., C.R. Gustavson, and K.W. Rusiniak. 1985b. Coyotes and taste aversion: the authors' reply. Appetite 6:284-290.

Gantz, G.F. 1990. Seasonal movement patterns of coyotes in the Bear River Mountains of Utah and Idaho. M.S. Thesis, Utah State Univ., Logan, Ut.

Garrott, R.A., P.J. White, and C.A. Vanderbilt White. 1993. Overabundance: an issue for conservation biologists? Conserv. Biol. 7:946-949.

General Accounting Office. 1990. Wildlife management effects of Animal Damage Control program on predators GAO/RCED-90-149, U.S. General Accounting Office, Washington, D.C.

Gee, C.K., R.S. Magleby, D.B. Nielsen, and D.M. Stevens. 1977. Factors in the decline of the western sheep industry. USDA Econ. Res. Serv., Agr. Econ. Rep. No. 377.

Gese, E.M. and S. Grothe. 1995. Analysis of coyote predation on deer and elk during winter in Yellowstone National Park, Wyoming. Amer. Midl. Natur. 133:36-43.

Gese, E.M. and R.L. Ruff. 1997. Scentmarking by coyotes, Canis latrans: the influence of social and ecological factors. Anim. Behav. 54:1155-1166.

Gese, E.M. and R.L. Ruff. 1998. Howling by coyotes (Canis latrans): variation among social classes, seasons, and pack sizes. Can. J. Zool. 76:1037-1043.

Gese, E.M., O.J. Rongstad, and W.R. Mytton. 1988. Home range and habitat use of coyotes in southeastern Colorado. J. Wildl. Manage. 52:640-646.

Gese, E.M., O.J. Rongstad, and W.R. Mytton. 1989. Population dynamics of coyotes in southeastern Colorado. J. Wildl. Manage. 53:174-181.

Gese, E.M., R.L. Ruff, and R.L. Crabtree. 1996a. Social and nutritional factors influencing the dispersal of resident coyotes. Anim. Behav. 52:1025-1043.

Gese, E.M., R.L. Ruff, and R.L. Crabtree. 1996b. Foraging ecology of coyotes (Canis latrans): the influence of extrinsic factors and a dominance hierarchy. Can. J. Zool. 74:769-783.

Gese, E.M., R.L. Ruff, and R.L. Crabtree. 1996c. Intrinsic and extrinsic factors influencing coyote predation of small mammals in Yellowstone National Park. Can. J. Zool. 74:784-797.

Gier, H.T. 1968. Coyotes in Kansas (revised). Kansas State Coll. Agr. Exp. Sta. Bull. 393. 118 pp.

Gluesing, E.A., D.F. Balph, and F.F. Knowlton. 1980. Behavioral patterns of domestic sheep and their relationship to coyote predation. Appl. Anim. Ethol. 6:315-330.

Gober, D.R. 1979. Factors affecting domestic sheep losses to predators in TransPecos, Texas. Ph.D. Diss., Texas A\&M Univ., College Station, Tex.
Green, J.S. and R.A. Woodruff. 1983. The use of three breeds of dog to protect rangeland sheep from predators. Appl. Anim. Ethol. 11:141-161.

Green, J.S. and R.A. Woodruff. 1987. Livestock-guarding dogs for predator control, p. 62-68. In: J. S. Green (ed.), Protecting livestock from coyotes. USDA Agric. Res. Serv., U.S. Sheep Exp. Sta., Dubois, Ida.

Green, J.S., F.R. Henderson, and M.D. Collinge. 1994. Coyotes, p. C51-C76. In: S. E. Hygnstrom, R. M. Timm, and G. E. Larson (eds.), Prevention and control of wildlife damage. Univ. Nebraska, Lincoln, Neb.

Green, J.S., R.A. Woodruff, and T.T. Tueller. 1984. Livestock-guarding dogs for predator control: costs, benefits and practicality. Wildl. Soc. Bull. 12:44-50.

Gustavson, C.R., J.R. Jowsey, and D.N. Milligan. 1982. A 3-year evaluation of taste aversion coyote control in Saskatchewan. J. Range Manage. 35:57-59.

Gustavson, C.R., J. Garcia, W.G. Hankins, and K.W. Rusiniak. 1974. Coyote predation control by aversive conditioning. Sci. 184:581-583.

Guthery, F.S. 1977. Efficacy and ecological effect of predator control in South Texas. Ph.D. Diss., Colorado State Univ., Fort Collins, Colo.

Guthery, F.S. and S.L. Beasom. 1977. Responses of game and nongame wildlife to predator control in South Texas. J. Range Manage. 30:404-409.

Hamlin, K.L., S.J. Riley, D. Pyrah, A.R. Dood, and R.J. Mackie. 1984. Relationships among mule deer fawn mortality, coyotes, and alternate prey species during summer. J. Wildl. Manage. 48:489-499.

Harris, C.E. 1983. Differential behavior of coyotes with regard to home range limits. Ph.D. Diss., Utah State Univ., Logan, Ut.

Harris, S. and G. Saunders. 1993. The control of canid populations. Symp. Zool. Soc. London 65:441-464.

Harrison, D.J. 1992. Dispersal characteristics of juvenile coyotes in Maine. J. Wildl. Manage. 56:128-138.

Henke, D.E. 1995. Effects of coyote control on their prey: a review, p. 35-40. In: D. Rollins, C. Richardson, T. Blankenship, K. Canon, and S. Henke (eds.), Coyotes in the southwest: a compendium of our knowledge. Tex. Parks Wildl. Dept., Austin, Tex.

Henne, F.R. 1975. Domestic sheep mortality on a western Montana ranch. M.S. Thesis, Univ. Montana, Missoula, Mont.

Henne, F.R. 1977. Domestic sheep mortality on a western Montana ranch, p. 133-146. In: R. L. Phillips and C. Jonkel (eds.), Proc. 1975 Predator Symp. Montana Forest and Conservation Exp. Sta., School of Forestry, Univ. Montana, Missoula, Mont.
Hibler, S.J. 1977. Coyote movement patterns with emphasis on home range characteristics. M.S. Thesis, Utah State Univ., Logan, Ut.

Hill, E.P., P.W. Sumner, and J.B. Wooding. 1987. Human influences on range expansion of coyotes in the southeast. Wildl. Soc. Bull. 15:521-524.

Hilton, H. 1978. Systematics and ecology of the eastern coyote, p. 209-228. In: M. Bekoff (ed.), Coyotes: biology, behavior, and management. Academic Press, New York, N.Y.

Hoffman, S.W. 1979. Coyote-prey relationships in Curlew Valley during a period of low jackrabbit density. M.S. Thesis, Utah State Univ., Logan, Ut.

Hoover, S. 1996. Effectiveness of volatile trigeminal irritants at reducing egg consumption by mammalian predators: an experimental analysis. M.S. Thesis, Utah State Univ., Logan, Ut.

Jelinski, D.E., R.C. Rounds, and J.R. Jowsey. 1983. Coyote predation on sheep, and control by aversive conditioning in Saskatchewan. J. Range Manage. 36:16-19.

Kauffeld, J.D. 1977. Availability of natural prey and its relationship to coyote predation on domestic sheep. M.S. Thesis, Univ. Nevada, Reno, Nev.

Kellert, S.R. 1985. Public perceptions of predators, particularly the wolf and coyote. Biol. Conserv. 31:167-189.

Kennelly, J.J. and B.E. Johns. 1976. The estrous cycle of coyotes. J. Wildl. Manage. 40:272-277.

Kirkpatrick, J.F. and J.W. Turner. 1991. Reversible contraception in nondomestic animals. J. Zoo Wildl. 22:392-408.

Knowlton, F.F. 1972. Preliminary interpretations of coyote population mechanics with some management implications. J. Wildl. Manage. 36:369-382.

Knowlton, F.F. and E.M. Gese. 1995. Coyote population processes revisited, $\mathrm{p}$. 1-6. In: D. Rollins, C. Richardson, T. Blankenship, K. Canon, and S. Henke (eds.), Coyotes in the southwest: a compendium of our knowledge. Tex. Parks Wildl. Dep., Austin, Tex.

Knowlton, F.F. and L.C. Stoddart. 1983. Coyote population mechanics: another look, p. 93-111. In: F. L. Bunnell, D. S. Eastman, and J. M. Peek (eds.), Symposium on natural regulation of wildlife populations. Forest, Wildl., and Range Exp. Station, Univ. Idaho, Moscow, Ida.

Knowlton, F. F. and L. C. Stoddart. 1992. Some observations from two coyote-prey studies, p. 101-121. In: A. Boer (ed.), Ecology and Management of the Eastern Coyote. Wildl. Res. Unit, Univ. New Brunswick, Fredericton.

Koehler, A.E., R.E. Marsh, and T.P. Salmon. 1990. Frightening methods and devices/stimuli to prevent animal damage a review. Proc. Vert. Pest Conf. 14:168173. 
Laundre' J.W. and B.L. Keller. 1984. Home-range size of coyotes: a critical review. J. Wildl. Manage. 48:127-139.

Lehner, P.N. 1987. Repellents and conditioned avoidance, p. 56-61. In: J. S. Green (ed.), Protecting livestock from coyotes. USDA Agric. Res. Serv. U.S. Sheep Exp. Sta., Dubois, Ida.

Linhart, S.B. 1984a. Managing coyote damage problems with nonlethal techniques: recent advances in research. Proc. Eastern Wildl. Damage Conf. 1:105-118.

Linhart, S.B. 1984b. Strobe-light and siren devices for protecting fenced-pasture and range sheep from coyote predation. Proc. Vert. Pest Conf. 11:154-156.

Linhart, S.B., H.H. Brusman, and D.S. Balser. 1968. Field evaluation of an antifertility agent, stilbesterol, for inhibiting coyote reproduction. Trans. North Amer. Wildl. Conf. 33:316-326.

Linhart, S.B., J.D. Roberts, and G.J. Dasch. 1982. Electric fencing reduces coyote predation on pastured sheep. J. Range. Manage. 35:276-281.

Linhart, S.B., R.T. Sterner, T.C. Carrigan, and D.R. Henne. 1979. Komondor guard dogs reduce sheep losses to coyotes: a preliminary evaluation. J. Range Manage. 32:238-241.

Linhart, S.B., R.T. Sterner, G.J. Dasch, and J.W. Theade. 1984. Efficacy of light and sound stimuli for reducing coyote predation upon pastured sheep. Prot. Ecol. 6:75-84.

Linhart, S. B., G. J. Dasch, R. R. Johnson, J. D. Roberts, and C. J. Packham. 1992. Electronic frightening devices for reducing coyote depredation on domestic sheep: efficacy under range conditions and operational use. Proc. Vert. Pest Conf. 15:386-392.

McAdoo, J. K. 1975. Predation on domestic sheep in northwestern Nevada. M.S Thesis, Univ. Nevada, Reno, Nev.

McAdoo, J.K. and D.A. Klebenow. 1978. Predation on range sheep with no predator control. J.Range. Manage. 31:111-114

Meadows, L.E. 1999. Efficacy of guard llamas (Lama glama) in reducing canid predation on domestic sheep. M.S. Thesis, Utah State Univ., Logan, Ut.

Mech, L.D. 1988. The Arctic wolf: living with the pack. Voyageur Press, Stillwater, Minn.

Mech, L.D. 1996. A new era for carnivore conservation. Wildl. Soc. Bull. 24:397-401.

Messier, F. and C. Barrette. 1982. The social system of the coyote (Canis latrans) in a forested habitat. Can. J. Zool. 60:1743-1753.

Miller, L.A. 1995. Immunocontraception as a tool for controlling reproduction in coyotes, p. 172-176. In: D. Rollins, C. Richardson, T. Blankenship, K. Canon, and S. Henke (eds.), Coyotes in the southwest: a compendium of our knowledge. Tex. Parks Wildl. Dep., Austin, Tex.

Mills, L.S., and F.F. Knowlton. 1991. Coyote space use in relation to prey abundance. Can. J. Zool. 69:1516-1521.
Moore, G.C. and G.R. Parker. 1992. Colonization by the eastern coyote (Canis latrans), p. 23-37. In: A. H. Boer (ed.), Ecology and management of the eastern coyote. Wildl. Res. Unit, Univ. New Brunswick, Fredericton.

Munoz, J.R. 1977. Causes of sheep mortality at the Cook Ranch, Florence, Montana, 1975-76. M.S. Thesis, Univ. Montana, Missoula, Mont.

Nass, R. D. and J. Theade. 1988. Electric fences for reducing sheep losses to predators. J. Range Manage. 41:251-252.

Nellis, C.H., and L.B. Keith. 1976. Population dynamics of coyotes in central Alberta, 1964-1968. J. Wildl. Manage. 40:389-399.

Nunley, G.L. 1995. The re-establishment of the coyotes in the Edward's Plateau of Texas, p. 55-64. In: D. Rollins, C. Richardson, T. Blankenship, K. Canon, and S. Henke (eds.), Coyotes in the southwest: a compendium of our knowledge. Tex. Parks Wildl. Dept., Austin, Tex.

O'Donoghue, M., S. Boutin, C.J. Krebs, and E.J. Hofer. 1997. Numerical responses of coyotes and lynx to the snowshoe hare cycle. Oikos 80:150-162.

O'Gara, B.W., K.C. Brawley, J.R. Munoz, and D.R. Henne. 1983. Predation on domestic sheep on a western Montana ranch. Wildl. Soc. Bull. 11:253-264.

Pearson, E.W. 1986. Current value of livestock losses to predators. Res. Info. Bull. No. 86-27, U.S. Fish Wildl. Serv., Denver Wildl. Res. Ctr., Denver, Colo. 20 pp.

Pearson, E.W. and M. Caroline. 1981. Predator control in relation to livestock losses in central Texas. J. Range Manage. 34:435-441.

Peterson, R.O. 1977. Wolf ecology and prey relationships on Isle Royale. U.S. Nat. Park Serv. Sci. Monogr. Ser. 11:1-210.

Phillips, M.K., R. Smith, V.G. Henry, and C. Lucash. 1995. Red wolf reintroduction program, p. 157-168. In: L. N. Carbyn, S. H. Fritts, and D. R. Seip (eds.), Ecology and conservation of wolves in a changing world. Can. Circumpolar Inst. Occas. Publ. 35, Edmonton, Alberta.

Powell, K.J. 1993. The use of guard llamas to protect sheep from coyote depredation. M.S. Thesis, Iowa State Univ., Ames, Iowa.

Reynolds, J.C., and S.C. Tapper. 1996. Control of mammalian predators in game management and conservation. Mammal Rev. 26:127-56.

Robel, R.J., A.D. Dayton, F.R. Henderson, R.L. Meduna, and C.W. Spaeth. 1981. Relationships between husbandry methods and sheep losses to canine predators. J. Wildl. Manage. 45:894-911.

Rollins, D. 1995. The livestock protection collar for removing depredating coyotes: a search for perfect justice? p. 168-171. In: D. Rollins, C. Richardson, T. Blankenship, K. Canon, and S. Henke (eds.), Coyotes in the Southwest: a compendium of our knowledge. Tex. Parks Wildl. Dept., Austin, Tex.
Sacks, B.N. 1996. Ecology and behavior of coyotes in relation to depredation and control on a California sheep ranch. M.S. Thesis, Univ. California, Berkeley, Calif.

Scrivner, J.H., W.E. Howard, A.H. Murphy, and J.R. Hays. 1985. Sheep losses to predators on a California range, 19731983. J. Range. Manage. 38:418-421.

Shelton, M. 1984. The use of conventional and electric fencing to reduce coyote predation on sheep and goats. Tex. Agr. Exp. Sta. MP 1556. 12 pp.

Shelton, M. 1987. Antipredator fencing, p. 30-37. In: J. S. Green (ed.), Protecting livestock from coyotes. USDA Agr. Res. Serv. U.S. Sheep Exp. Sta., Dubois, Ida.

Shivik, J.A. 1995. Factors influencing space use and activity of Sagehen Basin coyotes. M. S. Thesis, Univ. California, Berkeley, Calif.

Shivik, J.A., M.M. Jaeger, and R.H. Barrett. 1996. Coyote movements in relation to the spatial distribution of sheep. J. Wildl. Manage. 60:422-430.

Slate, D., R. Owens, G. Connolly, and G. Simmons. 1992. Decision making for wildlife damage management. Trans. North Amer. Wildl. Natur. Resour. Conf. 57:51-62.

Smith, R.H., D.J. Neff, and N.G. Woolsey. 1986. Pronghorn response to coyote control-a benefit: cost analysis. Wildl. Soc. Bull. 14: 226-231.

Sterner, R.T. and S.A. Shumake. 1978. Coyote damage-control research: a review and analysis, p. 297-325. In: M. Bekoff (ed.), Coyotes: biology, behavior, and management. Academic Press, New York, N.Y.

Stoddart, L.C., F.F. Knowlton, and R.J. Taylor. 1989. A first generation mathematical model for calculating area of influence and potential number of animals exposed to management programs, p. 28-33. In: K.A. Fagerstone and R.D. Curnow (eds.), Vert. Pest Control and Manage. Materials, Vol. 6. Amer. Soc. for Test. Mat. Spec. Tech. Publ. 1055.

Stream, L. 1976. 1976 lithium chloride taste aversion experiment in Whitman County, Washington. Final Rep., Wash. State Dep. Game. 18 pp.

Stuby, R.G., E.H. Carpenter, and L.M. Arthur. 1979. Public attitudes toward coyote control. USDA Econ. Stat. Coop. Serv., ESCS-54. 11 pp.

Teer, J.G., D.L. Drawe, T.L. Blankenship, W.F. Andelt, R.S. Cook, J.G. Kie, F.F. Knowlton, and M. White. 1991. Deer and coyotes: the Welder experiments. Trans. North Amer. Wildl. Natur. Resour. Conf. 56:550-560.

Terrell, C.E. 1988. Predator losses climb nationwide. Nat. Wool Grower 78:32-34.

Till, J.A., and F.F. Knowlton. 1983. Efficacy of denning in alleviating coyote depredations upon domestic sheep. J. Wildl. Manage. 47:1018-1025. 
Timm, R.M. and G.E. Connolly. 1980 How coyotes kill sheep. Nat. Wool grower. 70:14-15.

Timm, R.M., and R.H. Schmidt. 1989. Management problems encountered with livestock guarding dogs on the University of California, Hopland Field Station, p. 54-58. In: Great Plains Wildl. Damage Control Workshop. USDA, Forest Serv., General Tech. Rep. RM- 171 and Great Plains Agr. Counc. Publ.

Todd, A.W. and L.B. Keith. 1983. Coyote demography during a snowshoe hare decline in Alberta. J. Wildl. Manage. 47:394-404.

Todd, A.W., L.B. Keith, and C.A. Fischer. 1981. Population ecology of coyotes during a fluctuation of snowshoe hares. J. Wildl. Manage. 45:629-640.

Tzilkowski, W.M. 1980. Mortality patterns of radio-marked coyotes in Jackson Hole, Wyoming. Ph.D. Diss., Univ. Massachusetts, Amherst, Mass.

U.S. Department of Agriculture. 1991. Agricultural Statistics, 1990-91. Nat. Agr. Statistics Serv., Agr. Statistics Board, Washington, D.C.

U.S. Department of Agriculture. 1997. Agricultural Statistics, 1995-96. Nat. Agr. Statistics Serv., Agr. Statistics Board, Washington, D.C.

U.S. Fish and Wildlife Service. 1978. Predator damage in the west: a study of coyote management alternatives. U.S. Fish Wildl. Serv., Washington, D.C.
Wade, D.H. 1978. Coyote damage: a survey of its nature and scope, control measures and their application, p. 347-368. In: M. Bekoff (ed.). Coyotes: biology, behavior, and management. Academic Press, New York, N.Y.

Wade, D.H. 1982. Impacts, incidence and control of predators on livestock in the United States with particular reference to predation by coyotes. Spec. Publ. No. 10, Conc. for Agr. Sci. Tech., Ames, Iowa. 20 pp.

Wagner, F.H. 1981. Role of lagomorphs in ecosystems, p. 668-694. In: K. Meyers and C. D. MacInnes (eds.), Proc. World Lagomorph Conf., Univ. Guelph, Guelph, Ont.

Wagner, F.H. 1988. Predator control and the sheep industry. Regina Books, Claremont, Calif.

Wagner, K.K. 1997. Preventive predation management: an evaluation using winter aerial coyote hunting in Utah and Idaho. Ph.D. Diss., Utah State Univ., Logan, Ut.

Weaver, J.L. 1977. Coyote-food base relationships in Jackson Hole, Wyoming. M.S. Thesis, Utah State Univ., Logan, Ut.

Weaver, J.L. 1979. Influence of elk carrion upon coyote populations in Jackson Hole, Wyoming, p. 152-157. In: M. S. Boyce and L.D. Hayden-Wing (eds.), Symp. North American elk: ecology, behavior, and management. Univ. Wyoming, Laramie, Wyo.
Werner, S.J., A. El Hani, and J.R. Mason. 1997. Repellent coatings for irrigation hose: effectiveness against coyotes. J. Wildl. Res. 2:146-148.

Wilkinson, T. 1996. Why won't ADC stop its predator war? Defenders 71:6-13.

Windberg, L.A. 1995. Demography of a high-density coyote population. Can. J. Zool. 73:942-954.

Windberg, L.A. 1996. Coyote responses to visual and olfactory stimuli related to familiarity with an area. Can. J. Zool. 74:2248-2254.

Windberg, L A. and F.F. Knowlton. 1988. Management implications of coyote spacing patterns in southern Texas. J. Wildl. Manage. 52:632-640.

Windberg, L.A. and F.F. Knowlton. 1990. Relative vulnerability of coyotes to some capture procedures. Wildl. Soc. Bull. 18:282-290.

Windberg, L.A., H.L. Anderson, and R. M. Engeman. 1985. Survival of coyotes in southern Texas. J. Wildl. Manage. 49:301-307.

Windberg, L.A., S.M. Ebbert, and B.T. Kelly. 1997a. Population characteristics of coyotes in the northern Chihuahuan desert. Amer. Midl. Natur. 138:197-207.

Windberg, L.A., F.F. Knowlton, S.M. Ebbert, and B.T. Kelly. 1997b. Aspects of coyote predation on small experimental flocks of Angora goats. J. Range Manage. 50:226-230.

Zemlicka, D.E. 1995. Seasonal variation in the behavior of sterile and nonsterile coyotes. M.S. Thesis,Utah State Univ., Logan, Ut. 